\title{
Temporal changes within the (bladder) tumor microenvironment that accompany the therapeutic effects of the immunocytokine NHS-IL12
}

\author{
Y. Maurice Morillon $I^{1}$, Zhen Su², Jeffrey Schlom ${ }^{1 *+}$ (I) and John W. Greiner ${ }^{1+}$
}

\begin{abstract}
Background: While significant strides in the treatment of metastatic bladder cancer have been made with immune checkpoint inhibitors, the treatment of carcinoma in situ and non-muscle invasive, non-metastatic (superficial) human urothelial carcinoma, also termed non-muscle invasive bladder cancer (NMIBC), remains intractable with bacillus Calmette-Guerin (BCG) employed as the standard of care. In this study, an immunocytokine, NHS-mulL12, which consists of two molecules of murine IL-12 fused to NHS76, a tumor necrosis-targeting human IgG1, was examined as an immunotherapeutic in an orthotopic MB49 ${ }^{\text {luc }}$ bladder tumor model.
\end{abstract}

Methods: The antitumor activity of systemic administration of NHS-mulL12 was investigated on MB49luc tumors, an aggressive, bioluminescent orthotopic bladder cancer model. Temporal studies were carried out on MB49 ${ }^{\text {luc }}$ bladder tumors harvested during various time points during NHS-mulL12 treatment and cellular changes associated with the reduction in tumor burden following NHS-mulL12 were determined by flow cytometry. Effects of those changes on the proliferation/activation of lymphoid cells were also determined.

Results: Studies revealed a significant reduction in MB49 ${ }^{\text {luc }}$ bladder tumor burden occurring between days 3 and 6 after the third and final systemic administration of NHS-mulL12. Temporal analyses of the MB49luc bladder tumor microenvironment (TME) initially revealed a large accumulation of myeloid-derived suppressor cells (MDSCS) and macrophages that elicited potent immunosuppression. Immunosuppression was characterized by the inability of $\mathrm{CD}^{+}$and $\mathrm{CD}^{+} \mathrm{T}$ cells to respond to broad-based immune stimulants. NHS-mulL12 administration resulted in temporal-dependent reductions in the number of MDSCs, macrophages and tumor-associated TGF- $\beta$, which culminated in a re-ignition of $\mathrm{CD}^{+}$and $\mathrm{CD}^{+} \mathrm{T}$ cells to elicit potent antitumor responses against MB49 ${ }^{\text {luc }}$ bladder tumors.

Conclusions: These findings provide strong evidence that the systemic administration of an immunocytokine consisting of a tumor-targeting Ig through recognition of DNA and DNA-histone complexes coupled to mulL-12 can effectively target the bladder TME; this significantly reduces the myeloid cellular compartment and reverts an immunosuppressive to an immunopermissive TME, ultimately resulting in antitumor effects. These studies provide further rationale for the employment of NHS-IL12 as an immunomodulator and clinical immunotherapeutic for NMIBC.

Keywords: Non-muscle invasive bladder cancer, Immunotherapy, NHS-mulL12

\footnotetext{
* Correspondence: schlomj@mail.nih.gov

†Jeffrey Schlom and John W. Greiner contributed equally to this work

${ }^{1}$ Laboratory of Tumor Immunology and Biology, Center for Cancer Research,

National Cancer Institute, Bethesda, MD, USA

Full list of author information is available at the end of the article
}

(c) The Author(s). 2019 Open Access This article is distributed under the terms of the Creative Commons Attribution 4.0 International License (http://creativecommons.org/licenses/by/4.0/), which permits unrestricted use, distribution, and reproduction in any medium, provided you give appropriate credit to the original author(s) and the source, provide a link to the Creative Commons license, and indicate if changes were made. The Creative Commons Public Domain Dedication waiver (http://creativecommons.org/publicdomain/zero/1.0/) applies to the data made available in this article, unless otherwise stated. 


\section{Introduction}

Bladder cancer is the fifth most common cancer in the United States [1] and, until recently, few new treatment approaches had emerged. Coupling an understanding of mutational heterogeneity underlying the influx of immune cells with the suppressive actions of the PD-1/PDL1 axis has led to the development and regulatory approval of immune cell checkpoint inhibitors, including avelumab (PD-L1), atezolizumab (PD-L1), durvalumab (PD-L1), pembrolizumab (PD-1), and nivolumab (PD-1), for the treatment of metastatic bladder cancer [2-6]. However, since the pioneering work of Morales et al. in 1976 [7], the standard of care for carcinoma in situ and non-muscle invasive, non-metastatic urothelial carcinoma remains the intravesical instillation of attenuated bacillus Calmette-Guerin (BCG). The mechanism of BCG action remains elusive, yet most investigators believe that the influx of immune cells is a crucial component [8]. Approximately $30-50 \%$ of patients do not respond initially to BCG or relapse within 5 years of treatment $[8,9]$. This limited effectiveness of BCG has underscored the need for additional therapies to reduce recurrence and improve survival for both BCG responders and non-responders.

IL-12 has been an intriguing cytokine due to its powerful proinflammatory effects that include proliferation of activated $\mathrm{T}$ cells and natural killer (NK) cells that promote potent $\mathrm{T}_{\mathrm{H} 1}$ cell-mediated immunity [10-13]. Preclinically, recombinant IL-12 (rIL-12) has remarkable antitumor effects against a wide range of malignancies, and has been linked to the generation of a strong antigen-specific immunological response and memory $[14,15]$. Translation of those potent $\mathrm{T}_{\mathrm{H} 1}$ properties into successful patient treatment has been stymied by doselimiting adverse events attributed to the systemic administration of rIL-12 [16]. Consequently, researchers have sought to develop novel approaches to selectively target IL-12 that might mitigate the systemic toxicities while taking advantage of its antitumor actions [17-21].

In previous studies $[17,22]$, instillation of murine rIL12 admixed with chitosan, a bioadhesive, significantly inhibited the growth of orthotopic MB49 $9^{\text {luc }}$ bladder tumors. Successful antitumor efficacy directed at the MB49 $9^{\text {luc }}$ bladder tumors was lost when either $\mathrm{CD}^{+}$or $\mathrm{CD}^{+} \mathrm{T}$ cells were absent, indicating the requirement of an intact host immune system. In the present study, murine IL-12 was administered as part of a fusion protein engineered by genetically fusing two murine IL-12 heterodimers to the $\mathrm{C}$-termini of the heavy chains of the NHS76 antibody. NHS76 is a fully human, phage display-derived IgG1 antibody that recognizes DNAhistone epitopes that are exposed within the necrotic regions of tumors $[23,24]$. In contrast to BCG, which is administered intravesically, NHS-Il12 is administered systemically. Previous studies highlight the advantages of delivering IL-12 as a fusion protein or "immunocytokine" over its administration as a recombinant protein $[18,23,25]$. Advantages include: (a) significant reduction of bioactivity (>90\%), i.e., less potential toxicity, by coupling murine IL-12 to the NHS76 antibody, (b) a sustained in vivo pharmacokinetic profile of NHS-muIL12, and (c) equal or superior antitumor activity when compared with rIL-12 in different types of murine tumors. The structure of NHS-IL12 has been previously reported [18]. Targeting of NHS-muIL12 through tumor necrosis-TNT antibody recognition should mitigate much of the systemic toxicity of rIL-12 administration, while delivering the potent $\mathrm{T}_{\mathrm{H} 1}$ cytokine to the tumor microenvironment (TME). While the robust anti-tumor properties of NHS-IL12 have been described [18], the present study examined the cellular events that accompanied antitumor efficacy within the MB49 $9^{\text {luc }}$ bladder TME following systemic administration of NHSmuIL12. In short, antitumor effects of NHS-muIL12 are associated with treatment-related reductions in myeloid derived suppressor cells (MDSCs) and macrophages and a return to an immunopermissive TME, which ultimately permits efficient tumor clearance via T cell-mediated killing.

\section{Materials and methods}

\section{Animals and cell lines}

Female C57BL/6 mice were purchased from The Jackson Laboratory or Charles River Laboratories and housed in microisolator cages in pathogen-free conditions. Mice used for in vivo antitumor studies were 16 to 18 weeks old at the start of study. Animal care followed The Guide for Care and Use of Laboratory Animals (National Research Council). MB49 parental (murine transitional bladder carcinoma) and MB49 $\mathrm{LucSH}^{+}$cells (MB49 ${ }^{\text {luc }}$ ) were grown and maintained as previously described [17].

\section{Murine tumor models}

Intravesical instillation of orthotopic MB49 $9^{\text {luc }}$ bladder tumors was carried out as previously described [17]. Tumor take was confirmed by in vivo imaging 7-10 days later, at which time mice were placed into appropriate treatment groups with equal tumor burden.

\section{Bioluminescent imaging}

Orthotopic bladder tumor growth was detected via IVIS Lumina In Vivo Imaging (Caliper Life Sciences, Alameda, CA). The abdominal regions of mice were shaved followed by intraperitoneal (i.p.) injection of $15 \mathrm{mg} / \mathrm{kg}$ luciferin salt $10 \mathrm{~min}$ prior to imaging. Anesthesia was administered by Forane (Isoflurane, USP, Baxter, Deerfield, IL) inhalation at $2 \%$ for the duration of imaging. Bioluminescence signal was read as total flux radiance 
(photons $/ \mathrm{sec} / \mathrm{cm}^{2} /$ steradian) using the Living Image Software, Version 4.1 (Caliper Life Sciences, Hanover, MD).

\section{Treatments}

NHS-muIL12, an immunocytokine consisting of a human IgG1 NHS-76 antibody and two murine IL-12 molecules, was kindly provided by EMD Serono under a Collaborative Research and Development Agreement (CRADA) with the NCI. NHS-muIL12 was stored at $+4 \mathrm{C}$ and diluted in Dulbecco's phosphate buffered saline (DPBS) prior to injection [18]. For anti-tumor studies, NHS-muIL12, a control human IgG1 or diluent was injected subcutaneously (s.c.) into the inner thigh. Mice were treated s.c., three times, 3 days apart. That treatment schedule allows for the delivery of biologically active NHS-muIL12 (i.e., IFN- $\gamma$ production) prior to the development of neutralizing murine antihuman Ig directed against the immunocytokine [18].

\section{In vitro immune suppression assay}

$\mathrm{CD} 45^{+}$cells were isolated from MB49 ${ }^{\text {luc }}$ bladder tumor homogenates of control Ig- or NHS-mulL12-treated animals at 5 days post-final NHS-muIL12 treatment. $\mathrm{CD} 45^{+}$cells were isolated via magnetic-activated cell sorting (MACS) separation using Miltenyi CD45+ Microbeads (Auburn, CA). T cells were isolated from the spleens of naïve C57BL/6 mice using the Miltenyi Pan T Cell Isolation Kit according to the manufacturer's specifications. Isolated cells were incubated at ratios of CD $45^{+}$tumor-derived cells to $\mathrm{T}$ cells ranging from 1:2 to $1: 128$. Cells were incubated in the presence of soluble $\alpha \mathrm{CD} 3$ (clone 145-2C11, eBioscience/Thermo Fisher, Waltham, MA) and $\alpha \mathrm{CD} 28$ (clone 27.51, eBioscience), $(0.5$ and $1.0 \mu \mathrm{g} / \mathrm{ml})$ for 2 days, after which cell proliferation was determined via Ki67 staining of live/blasting $\mathrm{T}$ cells using flow cytometry.

\section{Flow cytometry analysis}

Antibodies used for flow cytometry were purchased from BD Biosciences (San Jose, CA), eBioscience/Thermo Fisher, or BioLegend (San Diego, CA). Fluorescently conjugated antibodies specific for CD3 (145-2C11), CD4 (RM4-5), CD8 (53-6.7), FoxP3 (FJK-16 s), F4/80 (BM8), GR1 (RB6-8C5), CD11b (M1/70), CD44 (IM7), CD38 (90), Ly6G (1A8), Ly6C (AL-21), IFN- $\gamma$ (XMG1.2), and Ki67 (B56) were used for flow cytometry. Staining and cell counting was performed as previously described [26]. For the detection of intracellular IFN- $\gamma$, prior to staining/fixing, single cell suspensions were cultured for $5 \mathrm{~h}$ with Cell Stimulation Cocktail (eBioscience/Thermo Fisher); Golgi Plug/Brefeldin A (BD Bioscience) was added for the final $4.5 \mathrm{~h}$ of culturing. Cytometry data were acquired utilizing a three-laser FACSVerse (BD
Biosciences). Data were analyzed using FlowJo (FlowJo, LLC, Ashland, OR).

\section{Tumor cytokine detection}

MB49 $9^{\text {luc }}$ bladder tumors were collected from mice on day 6 post-final NHS-muIL12 treatment. Tumors were homogenized via mechanical dissociation and centrifuged at $500 \times$ g for $10 \mathrm{~min}$. Supernatants were removed, and tumors individually resuspended in EL-Lysis buffer containing Protease Inhibitors (Ray Biotech, Norcross, $\mathrm{GA}$ ), according to the manufacturer's recommendations. Levels of IFN- $\gamma$ and TGF- $\beta$ were measured in tumor lysates utilizing R\&D Systems Quantikine ELISA Kits (Minneapolis, MN).

\section{Statistical analysis}

GraphPad Prism software (GraphPad Prism 7 for Windows, GraphPad Software, Inc., La Jolla, CA) was used to perform all statistical analyses. Details of appropriate statistical analyses are found within each figure legend. Differences were significant when the $P$ value was $\leq 0.05$.

\section{Results}

Temporal antitumor effects of NHS-mulL12 in the MB49 $9^{\text {luc }}$ bladder tumor model

A previous study [27] reported a dose-dependent reduction of MB4 $9^{\text {luc }}$ bladder tumor growth in mice treated with 0.05 to $0.4 \mu \mathrm{g} \times 3$ NHS-muIL12 with $0.4 \mu \mathrm{g}$ NHSmuIL12 resulting in complete tumor regression in most mice. Of interest was to examine the cellular changes occurring within the MB49 $9^{\text {luc }}$ bladder TME during the time interval commensurate with the reductions in tumor growth following NHS-muIL12 treatment. In the present study, mice bearing MB49 ${ }^{\text {luc }}$ bladder tumors were treated with $0.4 \mu \mathrm{g}$ NHS-muIL12 on days 9,12 and 15 (Fig. 1a). Intra-vital imaging (Fig. 1b) and individual bladder weights (Fig. 1c) showed active MB49 ${ }^{\text {luc }}$ bladder tumor growth suppression between days 18 and 21 posttumor instillation, or 72 and $144 \mathrm{~h}$ after the final NHSmuIL12 treatment. At the 72-h time point, there were no discernable differences in MB49 $9^{\text {luc }}$ bladder tumor burden between the control Ig- and NHS-muIL12treated mice; luciferase-based images were similar (Fig. 1b) as were the bladder weights (i.e., control Ig, $190.2 \pm$ 65.7; NHS-muIL12, $161.1 \pm 50.2 \mathrm{mg}$ ) (Fig. 1c). At the 144-h time point, the average MB49 $9^{\text {luc }}$ bladder tumor weight from control Ig-treated mice was $312.4 \pm 72.1$ $\mathrm{mg}$, indicating ongoing MB49 ${ }^{\text {luc }}$ tumor growth, while those from NHS-muIL12-treated mice were $87.6 \pm 22.9$ $\mathrm{mg}$, indicating an ongoing treatment-related antitumor response (Fig. 1c). Thus, changes within the MB49 $9^{\text {luc }}$ bladder TME at 72 and $144 \mathrm{~h}$ after the final NHSmulL12 treatment seemed to contribute to the potent 


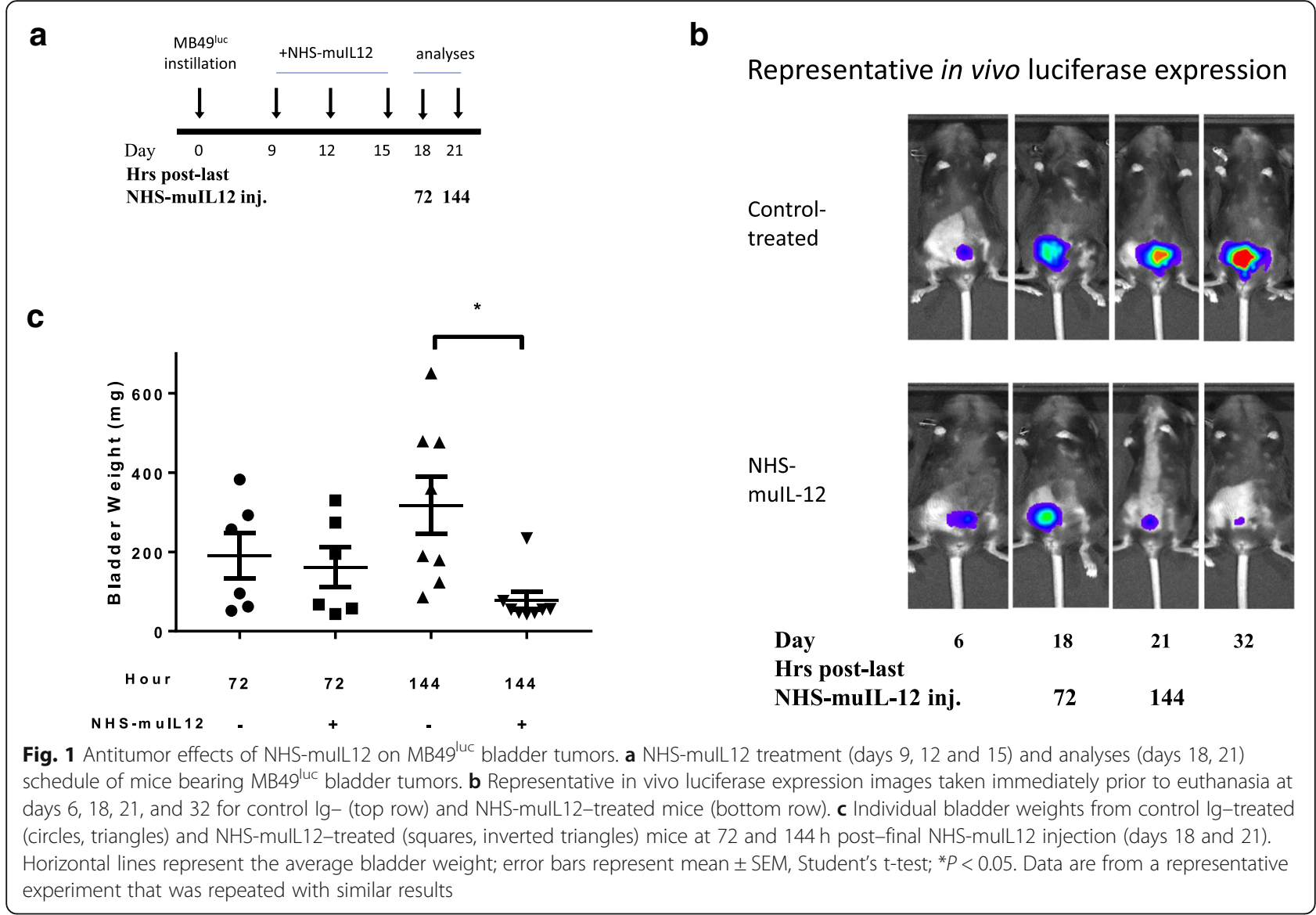

antitumor response and became the focus of subsequent study.

\section{Cellular changes in the MB49 $9^{\text {luc }}$ bladder TME during NHS- mulL12 immunotherapy}

Flow cytometry assessed both the frequencies and number of myeloid (MDSCs and macrophages) and lymphoid (i.e., $\mathrm{CD}_{4}^{+}, \mathrm{CD}^{+}, \mathrm{CD}^{+} \mathrm{FoxP}^{+}$) cells $/ \mathrm{mg} \mathrm{MB} 49^{\text {luc }}$ bladder weight at 72 and $144 \mathrm{~h}$ after the final NHS-muIL12 treatment. At the 72-h time point, representative FACS plots of the MB49 $9^{\text {luc }}$ bladder TME from control Ig- and NHS-muIL12-treated mice were similar with few (i.e., 3-5\%) $\mathrm{CD} 45^{+} \mathrm{CD}^{+} \mathrm{T}$ cells, but a preponderance (i.e., >

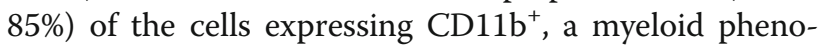
type (Fig. 2a, top row). Commensurate with the ongoing antitumor effects of NHS-muIL12, at the 144-h time point, the percentage of $\mathrm{CD}^{+} \mathrm{T}$ cells was $14 \%$ in the TME of NHS-muIL12-treated mice compared with $2.0 \%$ in the TME from control Ig-treated mice. The percentage of $\mathrm{CD}_{11 \mathrm{~b}^{+}}$myeloid cells fell from $94 \%$ in the control Ig-treated mice to $43 \%$ in the MB49 $9^{\text {luc }}$ bladder TME from NHS-muIL12-treated mice (Fig. 2a, bottom row). When the number of MDSCs $\left(\mathrm{Gr}^{+} \mathrm{CD}^{+} 1 \mathrm{~b}^{+} \mathrm{F} 4 /\right.$ $\left.80^{-}\right)$, macrophages $\left(\mathrm{Gr}^{-} \mathrm{CD} 11 \mathrm{~b}^{+} \mathrm{F} 4 / 80^{+}\right)$and $\mathrm{CD} 4^{+}$,
$\mathrm{CD}^{+}, \mathrm{CD}^{+} \mathrm{FoxP}^{+}$lymphoid cells were analyzed per mg bladder (Fig. 2b-f), more dramatic changes in both control Ig- and NHS-muIL12-treated mice emerged at the 72- and 144-h time points. In control Ig-treated mice, those changes included: (a) a 3-fold increase in MDSCs $(p<0.01$, Fig. 2b) and macrophages $(p=0.057$, Fig. 2c) and (b) trending higher numbers $(p=0.1)$ of $\mathrm{CD}^{+}, \mathrm{CD}^{+}$and $\mathrm{CD}^{+}{ }^{+} \mathrm{FoxP}^{+}{ }^{+} \mathrm{T}$ cells (Fig. 2d-f). In contrast, with NHS-muIL12 treatment, the accumulation of MDSCs and macrophages in the MB49 $9^{\text {luc }}$ bladder TME were blunted so that at the 144-h time point the numbers of both MDSCs and macrophages/mg bladder were significantly $(p<0.01)$ lower than those of the control Ig-treated mice (Fig. 2b, c). Similar trends were observed in the $\mathrm{T}$ cell compartment, where an increase in both $\mathrm{CD}^{+}$(Fig. 2d) and $\mathrm{CD}^{+}{ }^{+} \mathrm{T}$ cells (Fig. 2e) was observed in control Ig-treated mice from 72 to $144 \mathrm{~h}$. The number of $\mathrm{CD}^{+}{ }^{+} \mathrm{FoxP}^{+}$regulatory T cells/mg MB49 ${ }^{\text {luc }}$ bladder trended higher (not significant) in both the control Ig- and NHS-mulL12-treated mice (Fig. 2f) during the 72- and 144-h time interval. Dendritic $\left(\mathrm{CD} 11 \mathrm{c}^{+}\right)$and NK $\left(\mathrm{NK} 1.1^{+}\right)$cells were rare, but present in equal numbers, in MB49 ${ }^{\text {luc }}$ bladder TME from both control Ig- and NHS-mulL12-treated mice (data not shown). 

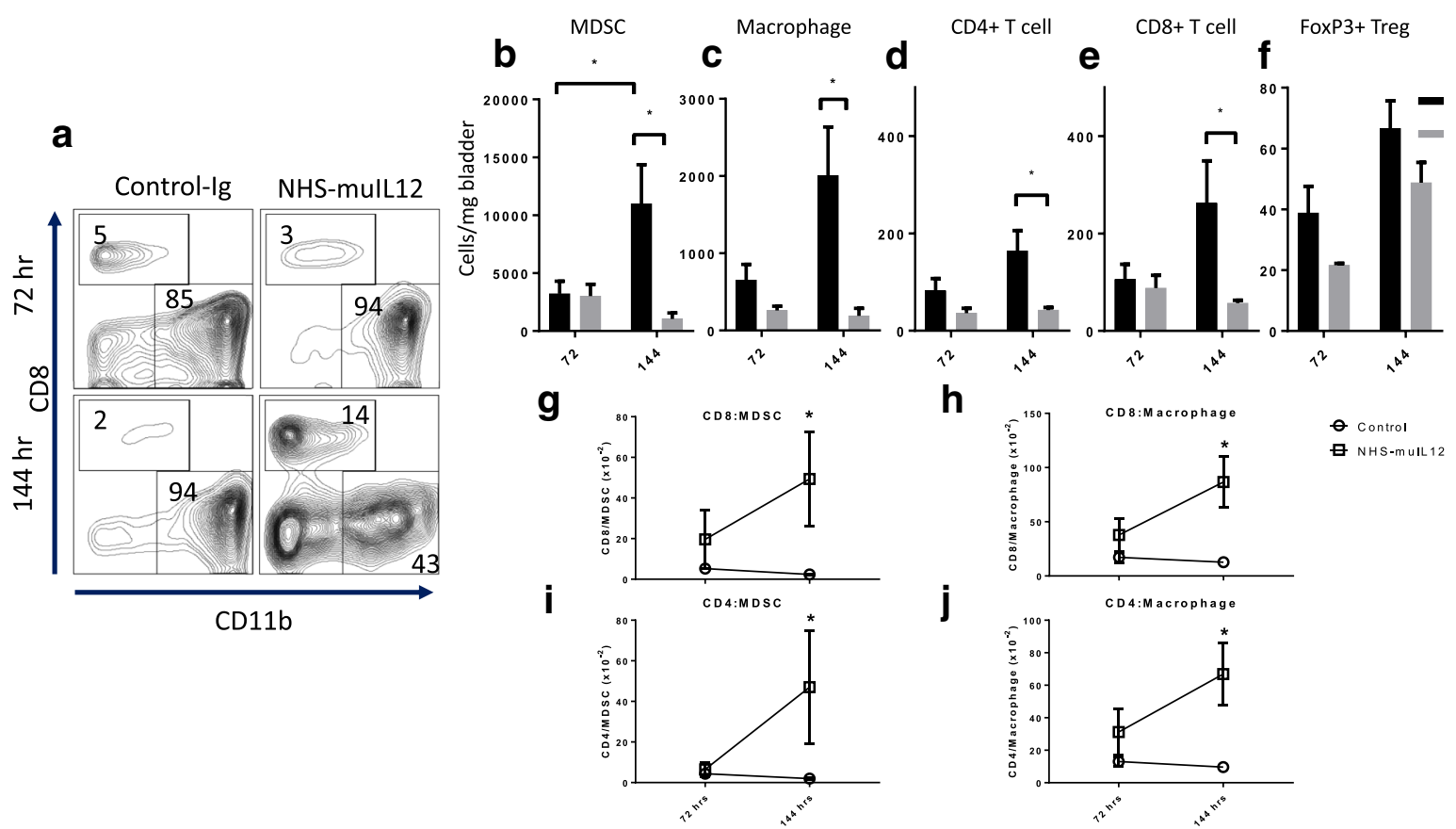

$e^{\mathrm{CD} 8+\mathrm{T} \text { cell }}$

FoxP3+ Treg

Fig. 2 Cellular changes in the MB49luc bladder TME of control Ig- and NHS-mulL12- treated mice at 72 and $144 \mathrm{~h}$ after the final NHS-mulL12 treatment. a Representative FACS plots of cytotoxic T lymphocytes (CD8, y-axis) vs myeloid (CD11b, x-axis) cells from control lg- (left column) and NHS-mulL12-treated (right column) mice bearing MB49 $9^{\text {luc }}$ bladder tumors. Plots are representative of live CD45 ${ }^{+}$tumor-derived cells at 72 (top row) and $144 \mathrm{~h}$ (bottom row) after the final NHS-mulL12 treatment. Numbers within each quadrant represent percent of total cells. In panels b-f, mice bearing MB49 ${ }^{\text {luc }}$ bladder tumors and treated with control Ig- (black bars) or NHS-mulL12 (grey bars) were euthanized at 72 and $144 \mathrm{~h}$ after the final NHS-mulL12 treatment and the lymphoid/myeloid cellular components within the TME were examined by flow cytometry. Absolute number of each cell type/mg bladder weight for (b) MDSCs: CD11 b $\mathrm{Gr}^{+}{ }^{+} \mathrm{F} 4 / 80^{-}(n=9)$, (c) macrophages: CD11 $\mathrm{b}^{+} \mathrm{Gr} 1^{-} \mathrm{F} 4 / 80^{+}(n=9),(\mathbf{d}) \mathrm{CD} 4^{+} \mathrm{T}$ cells $(n=9),(\mathbf{e}) C D 8^{+}$T cells $(n=9)$, and $(\mathbf{f})$ regulatory T cells (Tregs): $\mathrm{CD}^{+} \mathrm{CD}^{+} \mathrm{FoxP}^{+}(n=3)$ are shown. Panels $\mathbf{g}$-j represent ratios of $(\mathbf{g}) \mathrm{CD} 8^{+} /$ MDSCs, (h) $\mathrm{CD}^{+} /$macrophages, (i) CD4 $4^{+}$MDSCs, and (j) $\mathrm{CD}^{+} /$macrophages at 72 and $144 \mathrm{~h}$ after the final NHS-mulL12 treatment $(n=9)$. Circles and squares represent control Ig-treated and NHS-mulL12-treated mice, respectively. Error bars (panels b-j) represent mean + SEM, Student's ttest; ${ }^{*} P<0.05$. Data are from a representative experiment that was repeated twice with similar results

To further examine the dynamic cellular changes in the MB49 $9^{\text {luc }}$ bladder TME that accompanied NHSmuIL12 treatment, the changes in the ratios of lymphoid $\left(\mathrm{CD} 4^{+}\right.$and $\mathrm{CD}^{+} \mathrm{T}$ cells) to myeloid (MDSCs and macrophages) cells were determined at the 72 - and 144-h time points (Fig. 2g-j). Despite the differences in the number of $\mathrm{CD}^{+}, \mathrm{CD}^{+}$, MDSCs and macrophages per mg bladder weight (Fig. 2b-e) at $72 \mathrm{~h}$ post-NHS-muIL12 treatment, the ratios of $\mathrm{CD}^{+} / \mathrm{MDSC}$ (Fig. $2 \mathrm{~g}$ ), $\mathrm{CD}^{+} / \mathrm{mac}^{-}$ rophages (Fig. 2h), $\mathrm{CD} 4^{+} / \mathrm{MDSC}$ (Fig. 2i), and $\mathrm{CD} 4^{+} / \mathrm{mac}^{-}$ rophages (Fig. 2j) in the MB49 ${ }^{\text {luc }}$ bladder TME of control Ig- and NHS-muIL12-treated mice were remarkably similar. By $144 \mathrm{~h}$, however, those ratios in mice bearing MB49 $9^{\text {luc }}$ bladder tumors and treated with NHS-muIL12 were significantly higher than for control Ig-treated mice. For example, because of the ongoing accumulation of MDSCs (Fig. 2b) or macrophages (Fig. 2c) in the MB49 $9^{\text {luc }}$ bladder TME of control Ig-treated mice, the $\mathrm{CD}^{+}$: MDSCs/macrophage ratios fell (Fig. 2g, h), as did the $\mathrm{CD}^{+}{ }^{+}$:MDSCs/macrophage ratios (Fig. $2 \mathrm{i}$, j). In contrast, $\mathrm{CD} 4^{+} / 8^{+}$:MDSC and $\mathrm{CD}^{+} / 8^{+}$:macrophage ratios were all significantly $(p<0.05$; vs. control Ig-treated mice) increased in MB49 ${ }^{\text {luc }}$ bladder TME of NHS-muIL12treated mice at the 144-h time point (Fig. 2g-j, squares).

\section{Additional phenotypic changes within the MB49luc bladder TME following NHS-mulL12 treatment}

$\mathrm{Gr}^{+} \mathrm{CD} 11 \mathrm{~b}^{+} \mathrm{F} 4 / 80^{-}$MDSCs can be further divided into $\mathrm{Ly} 6 \mathrm{C}^{+}$monocytic and $\mathrm{Ly} 6 \mathrm{G}^{+}$granulocytic populations and depending on their contextual expression (e.g., tumor microenvironment, site of chronic inflammation) each can evoke immunosuppression via arginase I (Arg I) and inducible nitric oxide synthase (iNOS), thus inhibiting $\mathrm{T}$ cell activation $[28,29]$. In mice bearing $M B 49^{\text {luc }}$ bladder tumors and treated with NHS-muIL12, the sig-

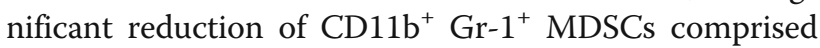
both the $\mathrm{Ly}_{6 \mathrm{C}} \mathrm{C}^{+}$and $\mathrm{Ly} 6 \mathrm{G}^{+}$populations (Fig. 3a, b); the reduction in the $\mathrm{CD}_{11} \mathrm{~b}^{+} \mathrm{Gr}-1^{+}$Ly6G ${ }^{+}$cells (Fig. 3b) was more pronounced than that for the monocytic $\mathrm{CD}_{11 b^{+}}$ Gr- $1^{+}$Ly6C $C^{+}$MDSCs (Fig. 3a).

The M1 polarization of $\mathrm{F} 4 / 80^{+}$macrophages was determined via staining with CD38 [30]. This inflammatory macrophage population was highest in MB49 ${ }^{\text {luc }}$ bladder tumors of NHS-muIL12-treated mice at $72 \mathrm{~h}$, followed 


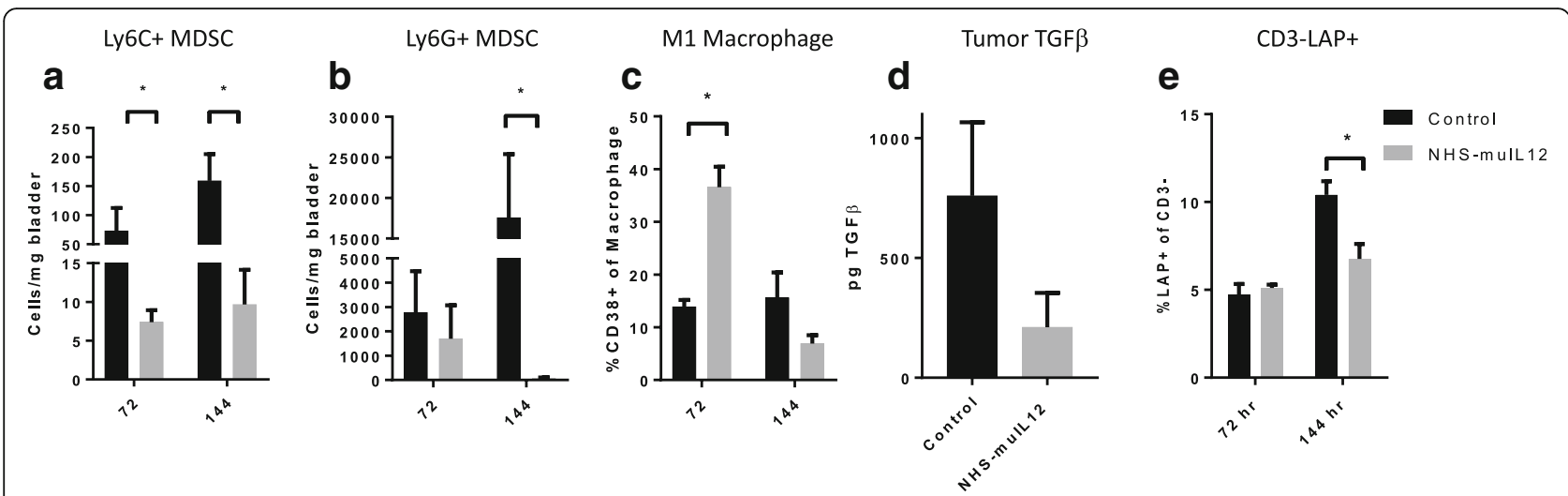

Fig. 3 Temporal-dependent phenotypic (72 and $144 \mathrm{~h}$ after the final NHS-mulL12 treatment) changes in myeloid/lymphoid cell profiles in the MB49 ${ }^{\text {luc }}$ bladder TME of control lg- (black bars) and NHS-mulL12-treated (grey bars) mice. Panels a-c represent differences in absolute number of cells/mg bladder weight of (a) $\mathrm{Ly}_{6 \mathrm{C}^{+}} \mathrm{MDSCs}$, (b) $\mathrm{Ly}_{6 \mathrm{G}}{ }^{+} \mathrm{MDSCs}$ and (c) in the frequencies of $\mathrm{M} 1$ of $\mathrm{CD} 11 \mathrm{~b}^{+} \mathrm{Gr} 1^{-} \mathrm{F} 4 / 80^{+}$macrophages. (d) Total tumor TGF- $\beta$ from control Ig- (black bars) and NHS-mulL12-treated (grey bars) mice at the 144-h time point $(n=5)$. e Frequencies of LAP ${ }^{+}$CD3 $^{-}$ cells. Error bars represent mean + SEM, Student's t-test; ${ }^{*} P<0.05$, unless otherwise indicated, $n=3$. Data are from a representative experiment that was repeated twice with similar results

by a sharp decline by $144 \mathrm{~h}$ post-final NHS-muIL12 treatment (Fig. 3c). Early upregulation of the immunopermissive M1 macrophage population may support the NHS-muIL12-mediated antitumor effects via an increase in the overall proinflammatory milieu.

At the study end, 6 days after the final NHS-mulL12 treatment, MB49 ${ }^{\text {luc }}$ bladder tumors from control Igand NHS-muIL12-treated mice were isolated, lysates prepared and total IFN- $\gamma$, IL-12 and TGF- $\beta$ quantitated. No differences were evident in either total IFN- $\gamma$ or IL12 levels in bladder tumor lysates from control Ig- and NHS-muIL12-treated mice (data not shown). In contrast, TGF- $\beta$ levels in the MB49 $9^{\text {luc }}$ bladder tumor lysates from NHS-mulL12-treated mice were reduced by approximately $60 \%$ when compared with levels in bladders of control Ig-treated mice (Fig. 3d). Consistent with reduced TGF- $\beta$ activation [31], expression of the latencyassociated peptide (LAP) in the non-lymphoid cell population (i.e., $\mathrm{CD}^{-} \mathrm{LAP}^{+}$, which is the $\mathrm{N}$-terminal propeptide of TGF- $\beta$ ) was significantly $(p<0.05)$ reduced at the 144-h time point within the MB49 $9^{\text {luc }}$ bladder TME of NHS-muIL12-treated vs. control Ig-treated mice (Fig. 3e).

\section{Functional immune suppression within the MB49luc bladder TME}

High numbers of MDSCs and macrophages in the MB49 $9^{\text {luc }}$ bladder TME of control Ig-treated mice would argue for a local immunosuppressive environment that could be reversed by treating with tumor targeting NHS-muIL12. To test that hypothesis, $\mathrm{CD} 45^{+}$cells were isolated from MB49 $9^{\text {luc }}$ bladder tumors of control Ig- or NHS-muIL12-treated mice on day 5 after the final NHS-muIL12 treatment. Those CD45-expressing cells were co-incubated with effector splenic $\mathrm{T}$ cells from naïve $\mathrm{C} 57 \mathrm{BL} / 6$ mice and $\mathrm{CD} 4^{+}$and $\mathrm{CD} 8^{+} \mathrm{T}$ cell proliferative response to $\mathrm{CD} 3 / 28$ stimulation was measured via Ki67-expression. Consistent with an active cell-mediated immunosuppressive TME, co-culturing $\mathrm{CD}^{+} 5^{+}$cells from MB49 ${ }^{\text {luc }}$ bladder tumors from control Ig-treated mice with splenic effector cells reduced the percentage of Ki67-expressing splenic $\mathrm{CD} 4^{+}$and $\mathrm{CD}^{+}$cells in response to $\alpha \mathrm{CD} 3 / 28$ to 21.3 and $40.2 \%$, respectively (Fig. 4a, left panels). In contrast, no such reduction in the $\mathrm{CD}_{4}^{+}$and $\mathrm{CD}^{+} \mathrm{T}$ cell proliferative response to $\alpha \mathrm{CD} 3 / 28$ was observed with the addition of $\mathrm{CD} 45^{+}$cells from the MB49 ${ }^{\text {luc }}$ bladders of NHS-mulL12-treated mice, suggesting little or no cell-mediated immunosuppression (Fig. 4a, middle panels). As a positive control, in the absence of bladder tumor isolated $\mathrm{CD} 45^{+}$cells, the percentage of splenic $\mathrm{CD} 4^{+}$and $\mathrm{CD} 8^{+} \mathrm{T}$ cells from naive mice that expressed Ki67 following $\alpha \mathrm{CD} 3 / 28$ in vitro stimulation was 66.6 and $81.6 \%$, respectively (Fig. 4a, right panels: labeled $\mathrm{T}$ cells only). Suppression of $\mathrm{CD}_{4}^{+}$(Fig. 4b) and $\mathrm{CD}^{+} \mathrm{T}$ cells (Fig. 4c) in response to $\alpha \mathrm{CD} 3 / 28$ stimulation was dependent on the number of $\mathrm{CD} 45^{+}$cells isolated from MB49 $9^{\text {luc }}$ bladder tumors and added to the suppression assay. Co-incubation of CD45 cells isolated from MB49 $9^{\text {luc }}$ bladder tumors of control Ig-treated mice with either $\mathrm{CD} 4^{+}$or $\mathrm{CD} 8^{+} \mathrm{T}$ cells from naïve mice (ratios of 1:2 and 1:4) significantly reduced the percentage of $\mathrm{CD}^{+}$or $\mathrm{CD}^{+} \mathrm{T}$ cells expressing Ki67 (Fig. 4b, c). That suppression of $\mathrm{CD}^{+}{ }^{+}$or $\mathrm{CD} 8^{+}$ $\mathrm{T}$ cells was either significantly reduced (Fig. $4 \mathrm{~b}$ ) or eliminated (Fig. 4c) when utilizing $\mathrm{CD} 45^{+}$cells isolated from NHS-mulL12-treated tumors, suggesting a reversal of immune-cell suppression within the MB49 $9^{\text {luc }}$ bladder TME. Hashed lines represent effector 


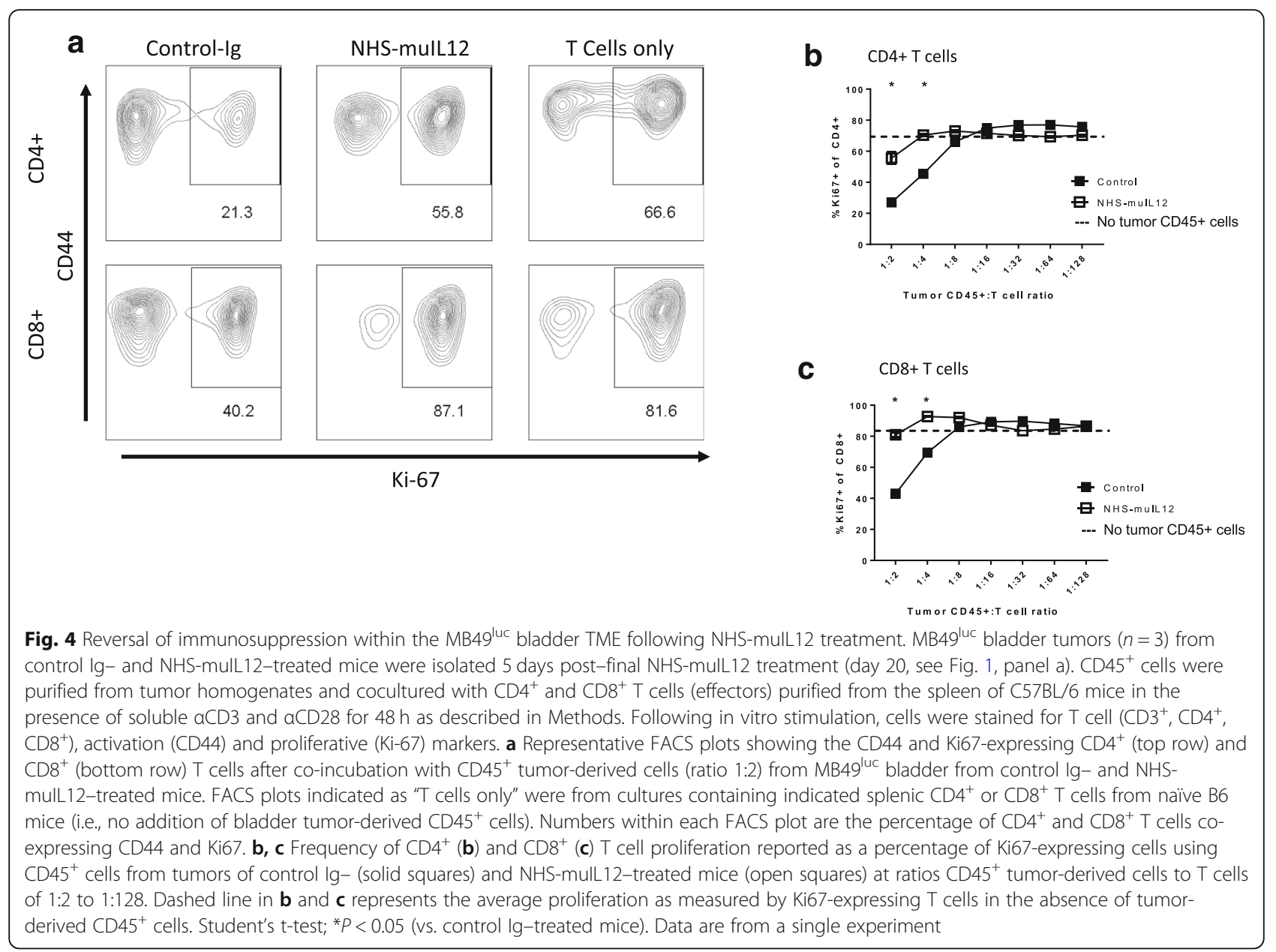

$\mathrm{T}$ cell proliferation in the absence of tumor-derived CD $45^{+} \mathrm{T}$ cells.

\section{Immune cell activation in the MB49 ${ }^{\text {luc }}$ bladder TME following NHS-mulL12 treatment}

Significant reduction in the number of myeloid cells within the TME coincided with growth suppression of MB49 $9^{\text {luc }}$ bladder tumors (Fig. 1c). Furthermore, previous findings established that $\mathrm{CD} 4^{+}$and $\mathrm{CD} 8^{+} \mathrm{T}$ cells were both required for the antitumor effects of NHS-muIL12 treatment of mice bearing MB49 $9^{\text {luc }}$ bladder tumors [27]. Those observations argued that the decrease in the number of myeloid cells might be tied to changes in the suppression/activation status of $\mathrm{CD} 4^{+}$and $\mathrm{CD} 8^{+} \mathrm{T}$ cells within the bladder TME. To examine that relationship, the activation status of $\mathrm{CD}^{+}$and $\mathrm{CD} 8^{+} \mathrm{T}$ cells within the MB49 $9^{\text {luc }}$ bladder TME from control Ig- and NHSmulL12-treated mice were examined. In the MB49 $9^{\text {luc }}$ bladder TME from control Ig-treated mice, the percentage of $\mathrm{CD} 4^{+}$and $\mathrm{CD} 8^{+} \mathrm{T}$ cells expressing CD44, a $\mathrm{T}$ cell activation marker, dropped from 47 to $43 \%$ at $72 \mathrm{~h}$ to 26 and $31 \%$ at $144 \mathrm{~h}$, respectively, suggesting ongoing/ increasing suppression of both immune cell subsets (Fig. 5a, b). No such drop in $\mathrm{CD}^{+}$and $\mathrm{CD}^{+} \mathrm{T}$ cells expressing CD44 was found in the MB49 $9^{\text {luc }}$ bladder TME from NHS-mulL12-treated mice (Fig. 5a, b). Figure 5c shows a representative FACS analysis of intracellular IFN- $\gamma$ expression by $\mathrm{CD}^{+}$and $\mathrm{CD}^{+}{ }^{+} \mathrm{T}$ cells, a marker for a $\mathrm{T}_{\mathrm{H} 1}$ response and CTL precursor cells, isolated from MB49 $9^{\text {luc }}$ bladder tumors from control Ig- and NHS-muIL12-treated mice. The top row illustrates an increased percentage of $\mathrm{CD} 4^{+} \mathrm{T}$ cells that stained positive for intracellular IFN- $\gamma$ production in the MB49 $9^{\text {luc }}$ bladder TME of NHS-muIL12-treated (i.e., 29.5\%) versus control Ig-treated (i.e., 9.12\%) mice (Fig. 5c). No such change was found within the $\mathrm{CD}^{+} \mathrm{T}$ cell population in the TME of NHS-muIL12-treated mice (Fig. 5c, bottom row). At 72 and $144 \mathrm{~h}$ after the final NHSmuIL12 treatment, cytometric analyses revealed significant increases in the percentage of $\mathrm{CD}^{+} / \mathrm{IFN}^{+} \gamma^{+} \mathrm{T}$ cells in the MB49 $9^{\text {luc }}$ bladder TME of NHS-muIL12 versus control Ig-treated mice (Fig. 5d). No such increase was found in the $\mathrm{CD} 8^{+} \mathrm{T}$ cell subset (Fig. 5e). Consistent with heightened immunosuppression at the 72- and 144- 


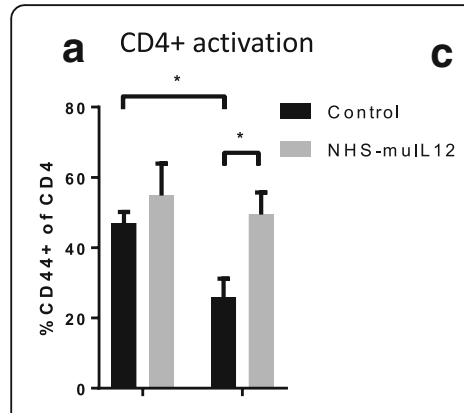

C

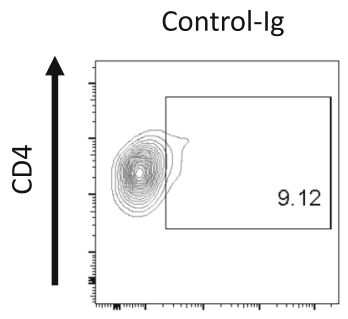

b CD8+ activation

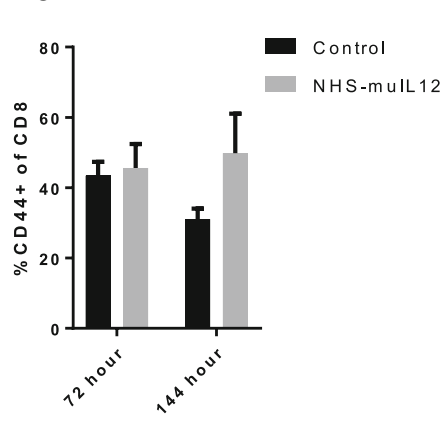

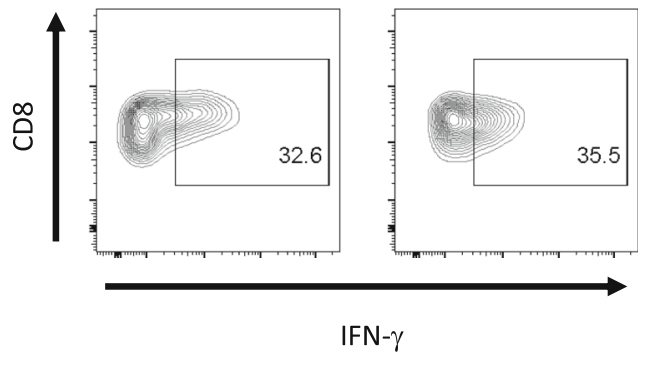

d

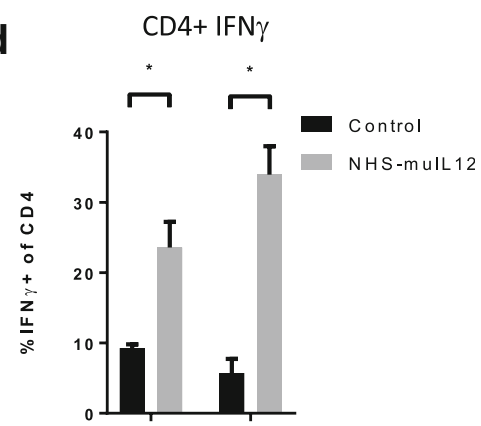

e

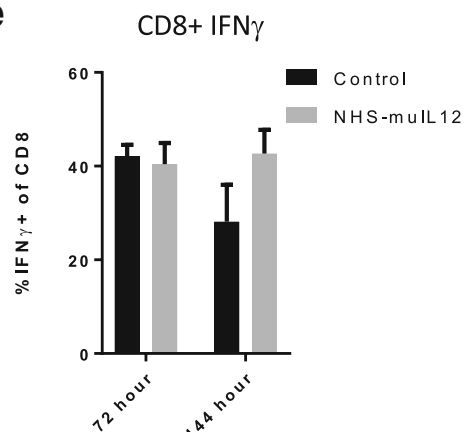

Fig. 5 NHS-mulL12 treatment increases T cell activation (CD44 expression) and pro-inflammatory events (i.e., intracellular IFN- $y$ expression) within the MB49 $9^{\text {luc }}$ bladder TME. a, b MB49 $9^{\text {luc }}$ bladder tumors $(n=3)$ from control Ig- (black bars) and NHS-mulL12-treated (grey bars) mice were isolated at 72 and $144 \mathrm{~h}$ post-final NHS-mulL 12 treatment and single cell suspensions were prepared (see Methods) and stained for CD4 ${ }^{+}, \mathrm{CD} 8^{+} \mathrm{T}$ cells along with the CD44 activation marker. c Representative FACS plots for intracellular IFN- $y$ staining of CD4 ${ }^{+}$and $C D 8^{+} \mathrm{T}$ cells after a 5-h in vitro stimulation (see Methods). $\mathbf{d}$, e Frequencies of $\mathrm{CD}^{+}$and $\mathrm{CD} 8^{+} \mathrm{T}$ cells expressing intracellular IFN- $\gamma$ from MB49 ${ }^{\text {luc }}$ bladder tumors from control Ig- (black bars) and NHS-mulL12-treated (grey bars) mice at 72 and $144 \mathrm{~h}$ post-final NHS-mulL12 administration. Error bars (panels a, b, d, e) represent mean \pm SEM. Student's t-test; ${ }^{*} P<0.05$ (vs. control-treated mice)

h time points, a trending reduction of $\mathrm{CD}^{+} / \mathrm{IFN}-\gamma^{+} \mathrm{T}$ cells was present in the MB49 $9^{\text {luc }}$ bladder TME of control Ig-treated mice (Fig. 5e).

\section{Discussion}

Efforts to identify novel approaches to improve upon the use of BCG as the standard of care for carcinoma in situ and non-muscle invasive, non-metastatic urothelial carcinoma have relied upon a syngeneic murine model of orthotopic instillation of MB49 transitional bladder tumor cells $[17,20]$. Known characteristics of the MB49 $9^{\text {luc }}$ bladder tumor model include early tumor necrosis and an immunosuppressive $\left(\mathrm{T}_{\mathrm{H} 2}\right.$ polarized) TME governed by IL-10 signaling [32-34]. In the present study, the immunosuppressive MB49 $9^{\text {luc }}$ bladder TME was further characterized by the presence of high numbers of myeloid-derived cells, primarily $\mathrm{CD} 11 \mathrm{~b}^{+} \mathrm{Gr} 1^{+} \mathrm{F} 4 /$

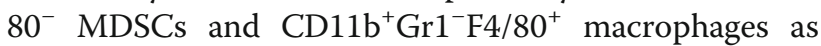
well as functional suppression of $\mathrm{CD}^{+}$and $\mathrm{CD} 8^{+} \mathrm{T}$ cell activation that underscored the inability of resident $\mathrm{CD}^{+} \mathrm{T}$ cells to control MB49 $9^{\text {luc }}$ bladder tumor growth. These data highlight the importance of the collection of biospecimens and evaluation of immunologic correlates, with particular emphasis on the analyses of MDSCs in patients with urothelial carcinoma [35, 36]. Systemic administration of NHS-muIL12, an immunocytokine that targets IL-12 to areas of tumor necrosis through recognition of exposed DNA-histone epitopes, proved to be a highly efficient immunotherapeutic in mice bearing orthotopic MB49 $9^{\text {luc }}$ bladder tumors.

While the anti-tumor efficacy conferred by NHSmuIL12 has been previously reported [18, 27], mechanistic characterization is still lacking. To address this, a temporal study was designed to identify those changes occurring within the MB49 $9^{\text {luc }}$ bladder TME during the time interval of maximum tumor regression, i.e., at 72 and $144 \mathrm{~h}$ after the third and final NHS-muIL12 administration (Fig. 1b, c). The findings revealed excellent concordance between the phenotypic and functional changes within the MB49 $9^{\text {luc }}$ bladder TME and the antitumor responses to systemic NHS-muIL12 administration. At $72 \mathrm{~h}$ post-third and final NHS-muIL12 treatment, the tumors still contained a preponderance of $\mathrm{CD}_{11 \mathrm{~b}^{+}} \mathrm{Gr}^{+} \mathrm{F} 4 / 80^{-} \mathrm{MDSC}$ and $\mathrm{CD} 11 \mathrm{~b}^{+} \mathrm{Gr} 1^{-} \mathrm{F} 4 / 80^{+}$ macrophages when compared with $\mathrm{CD} 4^{+}$and $\mathrm{CD} 8^{+} \mathrm{T}$ cells, arguing for an ongoing immunosuppressive TME (Fig. 2b, c). At the 72-h post-final NHS-muIL12 treatment, there was no discernable reduction in MB49 ${ }^{\text {luc }}$ 
bladder tumor burden, yet, there were cellular changes in the MB49 ${ }^{\text {luc }}$ bladder TME following NHS-muIL12 treatment that could represent early events that ultimately would provide an immunopermissive TME leading to $\mathrm{MB} 49^{\text {luc }}$ bladder tumor regression. Those changes include (1) decrease in the number of $\mathrm{Ly}_{6} \mathrm{C}^{+}$and $\mathrm{Ly} 6 \mathrm{G}^{+}$ MDSCs (Fig. 3a, b), (2) increase in M1 macrophages, as identified by CD38 expression [34] (Fig. 3c) and (3) increase in $\mathrm{CD}_{4}^{+} \mathrm{IFN}-\gamma^{+}$cells (Fig. 5d). Those changes would be expected to begin the conversion of the MB49 $9^{\text {luc }}$ bladder TME from one of immunosuppressive to proinflammatory following NHS-muIL12 treatment.

By $144 \mathrm{~h}$ after the final NHS-muIL12 treatment, the cellular makeup of the MB49 ${ }^{\text {luc }}$ bladder TME had dramatically changed with the number of MDSCs and macrophages significantly reduced which, in turn, remodeled the MB49 $9^{\text {luc }}$ bladder TME by increasing the ratios of $\mathrm{CD}^{+}$and $\mathrm{CD}^{+}$to $\mathrm{CD}^{+} 1 \mathrm{~b}^{+} \mathrm{Gr} 1^{+} \mathrm{F} 4 / 80^{-}$MDSCs and $\mathrm{CD}_{11 \mathrm{~b}}{ }^{+} \mathrm{Gr} 1^{-} \mathrm{F} 4 / 80^{+}$macrophages (Fig. 2g-j). When MDSCs were further divided into monocytic $\left(\mathrm{CD} 11 \mathrm{~b}^{+}\right.$ $\left.\mathrm{Gr}^{+} \mathrm{Ly}^{+} \mathrm{C}^{+} \mathrm{Ly}_{6 \mathrm{G}}{ }^{-}\right)$and granulocytic $\left(\mathrm{CD} 11 \mathrm{~b}^{+} \mathrm{Gr}^{+}\right.$ Ly6 ${ }^{\text {low }}$ Ly6G ${ }^{+}$), NHS-muIL12 treatment kept a low number of monocytic MDSCs while virtually eliminating granulocytic MDSCs within the MB49 ${ }^{\text {luc }}$ bladder TME (Fig. 3a, b). These data are consistent with a previous finding that a robust increase in intratumoral $\mathrm{CD}^{+} \mathrm{T}$ cell activation and proliferation resulted after targeted depletion of granulocytic MDSCs [37]. Those changes within the myeloid cell compartment provide compelling evidence for a reversal of cellular immunosuppression within the MB49 ${ }^{\text {luc }}$ bladder TME elicited by NHSmuIL12 treatment resulting in significant tumor regression. In addition, the drop in immunosuppressive myeloid cells was also accompanied by an increased response of $\mathrm{CD}_{4}^{+}$and $\mathrm{CD} 8^{+} \mathrm{T}$ cells to exogenous broadbased stimuli (Fig. 4). Thus, phenotypic/functional changes within the MB49 ${ }^{\text {luc }}$ bladder TME not only affirmed the tumor-targeting ability of NHS-muIL12, but also offered a plausible sequence of events that accompany the significant reductions observed in MB49 $9^{\text {luc }}$ bladder tumor burden. With the initial intravesical inoculation of MB49 ${ }^{\text {luc }}$ tumor cells, early intratumoral necrosis occurs that releases intrinsic tumor-associated antigens, which, in turn, induces a host immune response. Support for the intrinsically driven host immune response against intravesical MB49 $9^{\text {luc }}$ tumors includes accumulation of immune cells within the tumor mass of control Ig-treated mice [22]. The presence of antitumor immune cells in the MB49 $9^{\text {luc }}$ bladder TME is countered by a large number of immunosuppressive $\mathrm{CD} 11 \mathrm{~b}^{+} \mathrm{Gr} 1^{+}$ F4/80 $\mathrm{MDSCs}$ and $\mathrm{CD}^{-} 1 \mathrm{~b}^{+} \mathrm{Gr} 1^{-} \mathrm{F} 4 / 80^{+}$macrophages. Reduction in the number of MDSCs and macrophages following NHS-muIL12 targeting might also trigger a positive feedback loop wherein local IL-12 production supports IFN- $\gamma$ accumulation [38]; this reignites the cytolytic abilities of resident $\mathrm{CD} 4^{+}$and $\mathrm{CD}^{+} \mathrm{T}$ cells leading to the significant regression seen in the MB49 $9^{\text {luc }}$ bladder tumors. Support for this hypothesis includes: (a) in vivo depletion of either $\mathrm{CD} 4^{+}$or $\mathrm{CD}^{+} \mathrm{T}$ cells abrogates the antitumor effects of NHS-muIL12. In a previous study, MB49 $9^{\text {luc }}$ bladder tumor weights were reduced from $339 \pm 61 \mathrm{mg}$ to $137 \pm 36 \mathrm{mg}$ in non-T cell depleted NHS-muIL12-treated mice, while no such reductions were evident in NHS-muIL12-treated mice depleted of either $\mathrm{CD}_{4}^{+}$(bladder weights: $298 \pm 76 \mathrm{mg}$ ) or $\mathrm{CD}^{+} \mathrm{T}$ cells (bladder weights: $456 \pm 101 \mathrm{mg}$ ) [27], (b) regression of the MB4 $9^{\text {luc }}$ bladder tumors occurs at low doses of NHS-muIL12 (i.e., $0.4 \mu \mathrm{g} /$ injection), and (c) previous results demonstrate that targeting the PD1/PD-L1 axis also mediates regression of the MB49 $9^{\text {luc }}$ bladder tumors [22]. Indeed, successful gene therapy of the MB49 tumors utilizing antigen-specific $\mathrm{CD} 8^{+} \mathrm{T}$ cells engineered to secrete IL-12 has been associated with the promotion of dendritic cell maturation [29, 38, 39]. It is intriguing to point out that in the control Ig-treated mice, in which MB49 $9^{\text {luc }}$ bladder tumor burdens increased during the 72-144-h time interval, $\mathrm{CD}^{+}$and $\mathrm{CD}^{+}$effector $\mathrm{T}$ cell numbers (Fig. 2d, e) actually increased, yet their activation status fell (Fig. 5a and b), providing additional evidence for immunosuppression. With NHS-muIL12 treatment, the reductions of MB49 $9^{\text {luc }}$ bladder tumor growth was not accompanied by any discernable increase in the number of $\mathrm{CD} 4^{+}$and $\mathrm{CD}^{+}$effector T cells (Fig. 2d, e), yet their activation status was increased (Fig. $5 \mathrm{a}, \mathrm{b})$. Those findings argue that the resident $\mathrm{T}$ cells were not subject to any intrinsic and/or irreversible defect (e.g., lack of retention, recruitment, exhaustion), but when unshackled from immunosuppressive components they were able to elicit a robust antitumor response directed at the remaining MB49 $9^{\text {luc }}$ bladder tumor cells. Seemingly this switch from an immunosuppressive to an immunopermissive TME is the foundation for the significant antitumor responses observed following NHSmuIL12 treatment. In a recent phase I clinical study in patients diagnosed with metastatic carcinomas [40], the maximum tolerated dose (MTD) for NHS-IL12 was $16.8 \mu \mathrm{g} / \mathrm{kg}$, clearly within range of doses that elicited significant antitumor effects in the MB49 ${ }^{\text {luc }}$ non-muscle invasive bladder tumor model. It is intriguing to suggest an additional study of NHS-IL12 in the context of patients diagnosed with carcinoma in situ, and in patients with non-muscle invasive, non-metastatic urothelial carcinoma who are BCG-naïve and/or have not responded to BCG.

Comparing NHS-muIL12 as an immunotherapeutic in the present study with findings from a previous report [18] offers some intriguing differences between treating mice bearing MB49 s.c. versus intravesical (i.e., mucosal) 
bladder tumors. For instance, the dose range that significantly suppresses the growth of intravesical MB49 $9^{\text {luc }}$ bladder tumors $(0.05$ to $0.4 \mu \mathrm{g}$, ref. [27]) was, for the most part, ineffective when administered to mice bearing MB49 subcutaneous tumors [18]. Secondly, immune cell depletion studies showed that the prime effectors capable of inhibiting MB49 s.c. tumor were $\mathrm{CD}^{+} \mathrm{T}$ and NK cells, whereas to effectively reduce MB49 bladder tumors required both $\mathrm{CD} 4^{+}$and $\mathrm{CD} 8^{+} \mathrm{T}$ cells. Whether the differences in dosing and effector cells are tied to the underlining differences of tumor within the s.c. space versus the mucosa should be a focus of future studies.

Finally, it should be mentioned that NHS-muIL12 can be easily paired with avelumab, an anti-PD-L1 antibody. In preclinical studies, concurrent administration of these two immunotherapeutics resulted in additive/synergistic antitumor effects in both s.c. transplanted tumors (MC38, MB49) as well as the MB49 ${ }^{\text {luc }}$ bladder tumor model [41]. It is noted that metastatic bladder cancer, especially in patients treated with prior therapies, can have regions of tumor necrosis, and thus the potential for binding of NHS-IL12 and subsequent anti-tumor activity. Those results informed the design of a phase I clinical trial in which patients diagnosed with metastatic carcinoma were treated with a combination of NHS-IL12 and avelumab [42].

\section{Conclusions}

NHS-IL12 is a fusion protein comprised of a tumortargeting IgG associated with IL-12. Administration of NHS-IL12 offers the opportunity to target a potent $\mathrm{T}_{\mathrm{H} 1}$ cytokine to the TME, while mitigating the toxicities associated with systemic administration of recombinant IL-12. In the present study, targeting IL-12 to MB49 $9^{\text {luc }}$ bladder tumors reverts an immunosuppressive to an immunopermissive TME, inducing potent antitumor effects. The findings argue for the continued development of NHS-IL12 as an immunomodulator and potential clinical immunotherapeutic for non-muscle invasive bladder cancer and other cancers.

\footnotetext{
Abbreviations

Arg I: Arginase I; BCG: Bacillus Calmette-Guerin; CRADA: Cooperative Research and Development Agreement; DPBS: Dulbecco's phosphate buffered saline; i.p.: intraperitoneal; iNOS: inducible nitric oxide synthase; LAP: Latencyassociated peptide; MACS: Magnetic-activated cell sorting; MDSCs: Myeloidderived suppressor cells; MTD: Maximum tolerated dose; NK: Natural killer; r: recombinant; s.c.: subcutaneously; TME: Tumor microenvironment
}

\section{Acknowledgements}

The authors thank Garland Davis, Bertina Gibbs, and LaJuan Chase for their technical assistance. We also thank Debra Weingarten for her expert editorial assistance.

\section{Authors' contributions}

JWG, YMM, and JS conceived of and designed the studies. JWG and YMM conducted the experiments. JWG, YMM, and JS acquired, analyzed and interpreted the data. JWG, YMM, ZS and JS wrote, reviewed and approved the final manuscript.

\section{Funding}

This research was supported by the Intramural Research Program of the Center for Cancer Research, National Cancer Institute, National Institutes of Health, as well as through a Cooperative Research and Development Agreement (CRADA) between EMD Serono and the National Cancer Institute.

Availability of data and materials

The data generated and analyzed will be made available from the corresponding author on reasonable request.

\section{Ethics approval}

Animal care followed The Guide for Care and Use of Laboratory Animals (National Research Council).

\section{Consent for publication}

Not applicable.

\section{Competing interests}

Authors from the National Cancer Institute do not have any competing interests to disclose. Author from EMD Serono is an employee/officer of said company.

\section{Author details}

'Laboratory of Tumor Immunology and Biology, Center for Cancer Research, National Cancer Institute, Bethesda, MD, USA. ${ }^{2}$ EMD Serono, Rockland, MA, USA.

Received: 14 February 2019 Accepted: 16 May 2019

Published online: 11 June 2019

\section{References}

1. Jemal A, Siegel R, Ward E, Hao Y, Xu J, Murray T, et al. Cancer statistics, 2008. CA Cancer J Clin. 2008;58(2):71-96.

2. Inman BA, Longo TA, Ramalingam S, Harrison MR. Atezolizumab: a PD-L1blocking antibody for bladder cancer. Clin Cancer Res. 2017;23(8):1886-90.

3. Sharma P, Callahan MK, Bono P, Kim J, Spiliopoulou P, Calvo E, et al. Nivolumab monotherapy in recurrent metastatic urothelial carcinoma (CheckMate 032): a multicentre, open-label, two-stage, multi-arm, phase 1/2 trial. Lancet Oncol. 2016:17(11):1590-8.

4. Bellmunt J, de Wit R, Vaughn DJ, Fradet $Y$, Lee JL, Fong L, et al. Pembrolizumab as second-line therapy for advanced urothelial carcinoma. N Engl J Med. 2017;376(11):1015-26.

5. Massard C, Gordon MS, Sharma S, Rafii S, Wainberg ZA, Luke J, et al. Safety and efficacy of durvalumab (MED14736), an anti-programmed cell death ligand-1 immune checkpoint inhibitor, in patients with advanced urothelial bladder cancer. J Clin Oncol. 2016;34(26):3119-25.

6. Apolo AB, Infante JR, Balmanoukian A, Patel MR, Wang D, Kelly $K$, et al. Avelumab, an anti-programmed death-ligand 1 antibody, in patients with refractory metastatic urothelial carcinoma: results from a multicenter, phase ib study. J Clin Oncol. 2017;35(19):2117-24.

7. Morales A, Eidinger D, Bruce AW. Intracavitary Bacillus Calmette-Guerin in the treatment of superficial bladder tumors. J Urol. 1976:116(2):180-3.

8. Malmstrom PU, Wijkstrom H, Lundholm C, Wester K, Busch C, Norlen BJ. 5year followup of a randomized prospective study comparing mitomycin $\mathrm{C}$ and bacillus Calmette-Guerin in patients with superficial bladder carcinoma. Swedish-Norwegian Bladder Cancer Study Group. J Urol. 1999:161(4):1124-7.

9. Herr HW, Morales A. History of bacillus Calmette-Guerin and bladder cancer: an immunotherapy success story. J Urol. 2008;179(1):53-6.

10. Trinchieri G. Interleukin-12 and the regulation of innate resistance and adaptive immunity. Nat Rev Immunol. 2003;3(2):133-46.

11. Gately MK, Desai BB, Wolitzky AG, Quinn PM, Dwyer CM, Podlaski FJ, et al. Regulation of human lymphocyte proliferation by a heterodimeric cytokine, IL-12 (cytotoxic lymphocyte maturation factor). J Immunol. 1991;147(3):874-82.

12. Perussia B, Chan SH, D'Andrea A, Tsuji K, Santoli D, Pospisil M, et al. Natural killer (NK) cell stimulatory factor or IL-12 has differential effects on the proliferation of TCR-alpha beta+, TCR-gamma delta+ T lymphocytes, and NK cells. J Immunol. 1992;149(11):3495-502. 
13. Gately MK, Wolitzky AG, Quinn PM, Chizzonite R. Regulation of human cytolytic lymphocyte responses by interleukin-12. Cell Immunol. 1992;143(1):127-42.

14. Robertson MJ, Ritz J. Interleukin 12: basic biology and potential applications in cancer treatment. Oncologist. 1996;1 (1 \& 2):88-97.

15. Brunda MJ, Luistro L, Warrier RR, Wright RB, Hubbard BR, Murphy M, et al. Antitumor and antimetastatic activity of interleukin 12 against murine tumors. J Exp Med. 1993;178(4):1223-30.

16. Leonard JP, Sherman ML, Fisher GL, Buchanan LJ, Larsen G, Atkins MB, et al. Effects of single-dose interleukin-12 exposure on interleukin-12-associated toxicity and interferon-gamma production. Blood. 1997;90(7):2541-8.

17. Zaharoff DA, Hoffman BS, Hooper HB, Benjamin CJ Jr, Khurana KK, Hance KW, et al. Intravesical immunotherapy of superficial bladder cancer with chitosan/interleukin-12. Cancer Res. 2009;69(15):6192-9.

18. Fallon J, Tighe R, Kradjian G, Guzman W, Bernhardt A, Neuteboom B, et al. The immunocytokine NHS-IL12 as a potential cancer therapeutic. Oncotarget. 2014;5(7):1869-84.

19. Smith SG, Baltz JL, Koppolu BP, Ravindranathan S, Nguyen K, Zaharoff DA. Immunological mechanisms of intravesical chitosan/interleukin-12 immunotherapy against murine bladder cancer. Oncoimmunology. 2017; 6(1):e1259050

20. Nagarajan S, Selvaraj P. Glycolipid-anchored IL-12 expressed on tumor cell surface induces antitumor immune response. Cancer Res. 2002;62(10):2869-74.

21. Wang P, Li X, Wang J, Gao D, Li Y, Li H, et al. Re-designing Interleukin-12 to enhance its safety and potential as an anti-tumor immunotherapeutic agent. Nat Commun. 2017;8(1):1395

22. Vandeveer AJ, Fallon JK, Tighe R, Sabzevari H, Schlom J, Greiner JW. Systemic immunotherapy of non-muscle invasive mouse bladder cancer with avelumab, an anti-PD-L1 immune checkpoint inhibitor. Cancer Immunol Res. 2016;4(5):452-62.

23. Sharifi J, Khawli LA, Hu P, King S, Epstein AL. Characterization of a phage display-derived human monoclonal antibody (NHS76) counterpart to chimeric TNT-1 directed against necrotic regions of solid tumors. Hybrid Hybridomics. 2001;20(5-6):305-12.

24. Eckert F, Schmitt J, Zips D, Krueger MA, Pichler BJ, Gillies SD, et al. Enhanced binding of necrosis-targeting immunocytokine NHS-IL12 after local tumour irradiation in murine xenograft models. Cancer Immunol Immunother. 2016; 65(8):1003-13.

25. Paoloni M, Mazcko C, Selting K, Lana S, Barber L, Phillips J, et al. Defining the pharmacodynamic profile and therapeutic index of NHS-IL12 immunocytokine in dogs with malignant melanoma. PLoS One. 2015;10(6): e0129954

26. Morillon YM 2nd, Hammond SA, Durham NM, Schlom J, Greiner JW. Enhanced immunotherapy by combining a vaccine with a novel murine GITR ligand fusion protein. Oncotarget. 2017;8(43):73469-82.

27. Vandeveer AJ, Schlom J, Greiner JW. Abstract 1480: systemic immunotherapeutic efficacy of an immunocytokine, NHS-mulL12, in a superficial murine orthotopic bladder cancer model. Cancer Res. 2016;76(14 Suppl): 1480

28. Gajewski TF, Meng Y, Blank C, Brown I, Kacha A, Kline J, et al. Immune resistance orchestrated by the tumor microenvironment. Immunol Rev. 2006:213:131-45.

29. Kerkar SP, Goldszmid RS, Muranski P, Chinnasamy D, Yu Z, Reger RN, et al. IL-12 triggers a programmatic change in dysfunctional myeloid-derived cells within mouse tumors. J Clin Invest. 2011;121(12):4746-57.

30. Jablonski KA, Amici SA, Webb LM, Ruiz-Rosado Jde D, Popovich PG, PartidaSanchez $\mathrm{S}$, et al. Novel markers to delineate murine M1 and M2 macrophages. PLoS One. 2015;10(12):e0145342.

31. Miyazono K, Hellman U, Wernstedt C, Heldin CH. Latent high molecular weight complex of transforming growth factor beta 1. Purification from human platelets and structural characterization. J Biol Chem. 1988;263(13):6407-15.

32. Loskog A, Dzojic H, Vikman S, Ninalga C, Essand M, Korsgren O, et al. Adenovirus CD40 ligand gene therapy counteracts immune escape mechanisms in the tumor microenvironment. J Immunol. 2004;172(11):7200-5.

33. Halak BK, Maguire HC Jr, Lattime EC. Tumor-induced interleukin-10 inhibits type 1 immune responses directed at a tumor antigen as well as a nontumor antigen present at the tumor site. Cancer Res. 1999;59(4):911-7.

34. Newton MR, Askeland EJ, Andresen ED, Chehval VA, Wang X, Askeland RW, et al. Anti-interleukin-10R1 monoclonal antibody in combination with bacillus Calmette--Guerin is protective against bladder cancer metastasis in a murine orthotopic tumour model and demonstrates systemic specific anti-tumour immunity. Clin Exp Immunol. 2014;177(1):261-8.
35. Ornstein MC, Diaz-Montero CM, Rayman P, Elson P, Haywood S, Finke JH, et al. Myeloid-derived suppressors cells (MDSC) correlate with clinicopathologic factors and pathologic complete response (PCR) in patients with urothelial carcinoma (UC) undergoing cystectomy. Urol Oncol. 2018;36(9):405-12

36. Tzeng A, Diaz-Montero CM, Rayman PA, Kim JS, Pavicic PG Jr, Finke JH, et al. Immunological correlates of response to immune checkpoint inhibitors in metastatic urothelial carcinoma. Target Oncol. 2018;13(5):599-609.

37. Stromnes IM, Brockenbrough JS, Izeradjene K, Carlson MA, Cuevas C, Simmons RM, et al. Targeted depletion of an MDSC subset unmasks pancreatic ductal adenocarcinoma to adaptive immunity. Gut. 2014;63(11): 1769-81.

38. Steding CE, Wu ST, Zhang Y, Jeng MH, Elzey BD, Kao C. The role of interleukin-12 on modulating myeloid-derived suppressor cells, increasing overall survival and reducing metastasis. Immunology. 2011:133(2):221-38.

39. O'Donnell MA, Luo Y, Hunter SE, Chen X, Hayes LL, Clinton SK. Interleukin12 immunotherapy of murine transitional cell carcinoma of the bladder: dose dependent tumor eradication and generation of protective immunity. J Urol. 2004;171(3):1330-5.

40. Strauss J, Heery CR, Kim JW, Jochems C, Donahue RN, Montgomery AS, et al. First-in-human phase I trial of a tumor-targeted cytokine (NHS-IL12) in subjects with metastatic solid tumors. Clin Cancer Res. 2019;25(1):99-109.

41. Fallon JK, Vandeveer AJ, Schlom J, Greiner JW. Enhanced antitumor effects by combining an IL-12/anti-DNA fusion protein with avelumab, an anti-PDL1 antibody. Oncotarget. 2017;8(13):20558-71.

42. A Phase lb Open Label, Dose Finding Trial to Evaluate the Safety, Tolerability, and Pharmacokinetics of Avelumab in Combination with M9241 (NHS-IL12) in Subjects with Locally Advanced, Unresectable, or Metastatic Solid Tumors (NCT 02994953).

\section{Publisher's Note}

Springer Nature remains neutral with regard to jurisdictional claims in published maps and institutional affiliations.

\section{Ready to submit your research? Choose BMC and benefit from:}

- fast, convenient online submission

- thorough peer review by experienced researchers in your field

- rapid publication on acceptance

- support for research data, including large and complex data types

- gold Open Access which fosters wider collaboration and increased citations

- maximum visibility for your research: over $100 \mathrm{M}$ website views per year

At BMC, research is always in progress.

Learn more biomedcentral.com/submission 